\title{
Differences between Offer and Demand on the ICT specialist's Czech Labor Market
}

\author{
Petr Doucek ${ }^{1}$, Lea Nedomova ${ }^{1}$, Milos Maryska ${ }^{2}$ \\ University of Economics, Faculty of Informatics and Statistics, \\ ${ }^{1}$ Department of System Analysis and \\ ${ }^{2}$ Department of Information Technologies, W. Churchill sq. 4, Prague, Czech Republic; \\ \{doucek, nedomova, maryskam\}@vse.cz
}

Global changes in the information society are placing ever greater emphasis on professionals in all areas of human activity and in the area of ICT (Information and Communications Technology) especially. This article provides methodology how to measure knowledge level requirements on ICT specialists in business, ICT and non ICT skills in graduates of tertiary education level. It shows also an example of data collecting in academic sphere and among business unites. Practical experiences from the five years research are presented at the end of in this contribution. These results are successfully applied for human resource management and innovation management in competences of ICT professionals in small and medium enterprises (SMEs) in the Czech Republic.

Keywords: Information and Communication Technology (ICT), Human Resources in ICT, ICT Education, competencies in SMEs.

\section{Introduction}

The contemporary turbulent economic environment (Saee, 2004) places elevated emphasis on managerial skills in various fields. The same is also true of managerial abilities and skills in the area of introduction of information and communications technologies (ICT) into everyday economic practice and their subsequent operation. In 2010, almost $5.4 \%$ of the employed global population was working in positions of ICT professionals (OECD, 2010). Their knowledge must constantly expand and, simultaneously, the typical knowledge of ICT professionals (Frinking et al., 2005) is being increasingly combined with other non ICT knowledge, such as marketing, business, etc. (OECD, 2010; EC, 2010, Kunstova, 2011). Similar conclusions were drawn by (Fernandez, 2006), who states that a combination of ICT and non-ICT knowledge is more important for companies in selecting employees than only specific ICT knowledge. The general frame of requirements on ICT specialists in actual business was developed and presented by Joseph et al. (2007) - Figure 1.

This concept suggests three-level analysis framework as a guideline for research on ICT specialist's behavior. The upper level is the environmental analysis, which includes the ICT labor market, ICT technological trends and national cultures.
The middle level - the corporate level analysis focuses on the corporate level factors - ICT strategy, ICT structure and human resources practices. The lowest level represents the individual analysis. This level includes job related factors, individual attributes and perceived organizational factors. (Jing and Hoon, 2010). This framework was used by our research and development work, but not in the complex of all three levels. We investigated only the Individual level with special accent on individual knowledge and ICT and non-ICT skills in our research. There could be distinguished in practice two types of surveys linked to the area of knowledge and skills in ICT:

- surveys realized by the universities or educational institutions,

- $\quad$ surveys realized by non-educational institutions.

Similar surveys as ours were realized at a lot of universities in the world. For example two detail surveys were realized in Saudi Arabia (Al-Jabri and Fraihat, 2005) and in Croatia (Varga et al., 2004). The structure of knowledge analyzed in these surveys is similar to structure of knowledge analyzed by the authors of this paper. Non-technical skills of Australian business graduates are for example analyzed in Jackson D. and Chapman, E. (2012). But this survey was more generally focused then only on ICT specialists.

Received: $18^{\text {th }}$ May 2012; revised 20 th $^{\text {th }}$ Uly 2012; accepted $29^{\text {th }}$ August 2012 


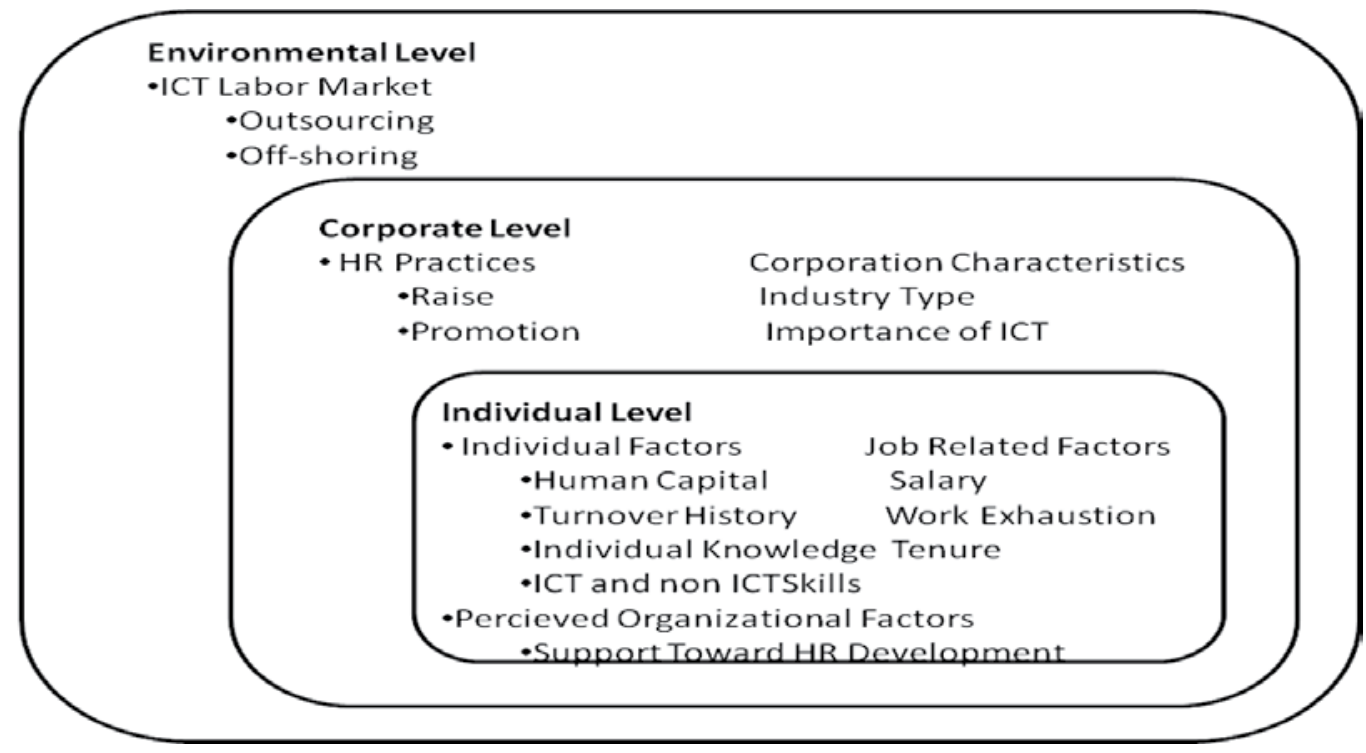

Figure 1: Research Framework for Turnover of ICT Professionals (Joseph et al., 2007)

Surveys aimed on assessing ICT knowledge are realized for example by Department of Labour Te Tari Mahi and ITCP on New Zeeland (Department of Labour, 2005) and (ITCP, 2012), ACS organization in Australia (Information, 2012).

\section{Problem Formulation}

As a reaction to the relatively low flexibility of the Czech Republic formal education system in the ICT skills area, six years ago the Faculty of Informatics and Statistics decided to initiate a research project in order to map:

- ICT education offered in the Czech Republic.

- Demand for ICT skills in the Czech Republic.

University education (tertiary education) forms an important component of the education system in each country in the world and this level should be one of the most effective and required in the area of ICT. Very similar ideas and questions are for example presented in Henno, Jaakkola, and Mäkelä (2012).

The aim of this project was to motivate universities and formulate recommendations for further development of the Czech university education in the area of ICT. To set up and formally pass the accreditation process of a new study program takes one year at least (only under conditions that relevant school or university has enough experts in required knowledge areas).

The main goal of our research was firstly to identify:

- The topics of education process and number of credits devoted to different IT subjects at all universities and technical specialist schools, which are involved in ICT education.

- The actual number of students, expected number of graduates in the actual school year and the actual number of new students in the first year.
The second goal was to carry out a survey of the ICT graduates skill requirements in the Czech market. The survey made among universities was performed three times (2006, 2009 and 2011) and the survey among companies two times (2006 and 2010). Our results could be compared with surveys about the acceptability of ICT university graduates in practice in other countries as for example are Marks and Huzzard (2012) and Wickramasinghe and Perera (2010).

\section{Methodology}

For realizing our research goals we had to solve some "side" problems. Main side problems were:

- To answer the question "Who is the ICT professional?" and "What are basic ICT roles in business?"

- What are the most important ICT skills and knowledge categories for each ICT business role?

- How to measure the level of knowledge and skills?

- What level of academic knowledge is acceptable for business?

\subsection{Roles in ICT - General Concept}

Our project prefers classification of specific roles in ICT (rather than particular professions which are in this context too detailed) underlining the competitive ability of graduates based on their knowledge potential (Valenduc and Vendramin, 2005). ICT specialist in this context is educated and qualified to use his/her knowledge potential mainly in the design, implementation and operation of ICT and their application (Round and Lovegrove, 2004; Clear, 2000). For the purpose of this project his/her competencies were described as follows:

- Design and development of ICT.

- Design and development of ICT applications. 
- Implementation, customization and integration of ICT applications within enterprise or other economic subject, thus changing and modifying working procedures and effectiveness of staff.

- Implementation and ICT operation management including user application support.

- Management of ICT projects.

- Information services management and knowledge distribution.

- ICT services and products promotion and purchase applying professional skills with aim to promote detail awareness of ICT services and products and promoting their effective use.

End users of ICT are not (for the purpose of this survey) considered as ICT specialists, even though most of the current university graduates (physicians, financiers and architects) are by definition active in data processing and computer-aided operations. This category was excluded as it does not require specific ICT education. For example, the user of SAP does not fit into our classification of an ICT specialist, but the methodology designer responsible for the overall SAP architecture is covered by our role definitions (Doucek et al., 2007).

Due to the fast developments and relatively high specialization in the area of ICT two levels of specialists were defined - the first level consists of core ICT roles with corresponding key knowledge and activities. This level is relevant for our research as it concentrates on the core competencies and procedures rather than on the detailed technical knowledge which universities could not provide in an up-to-date manner. The second level lists ICT professions included in the core roles
(Business Process Analyst/Designer, IS/ICT Development and Operations Manager, Dealer - Business Person in ICT Products and Services, Developer/ IS Architect, Administrator of Applications and of ICT Infrastructure and Lector in ICT). An example of the role description is presented in Table 1.

As is evident from Table 1, there were specified following attributes for each role - concrete professions in business informatics, key required knowledge and key business activities in corporate informatics.

Furthermore, there are some obligatory skills required for all ICT roles in each economy:

- high level of creativity,

- team work ability,

- communication competence,

- fluent spoken and written foreign language. For Europe in majority, English or other foreign languages depending on a region.

There were identified new knowledge requirements on ICT specialists, especially thanks to the social networks boom, during working out our tasks (Doucek et al., 2011b):

1. There will be a higher expectancy of communication skills for webmasters/profile managers. Interactive nature of social network requires an empathy and social sensibility.

2. There will be a growing demand for Facebook developers, fluent in the Facebook Markup Language (FBML). Also Facebook/LinkedIn application programmer will be needed.

3. Since Facebook is highly multi-language environment, we can expect higher demand for foreign languages.

Table 1: ICT Professions - Developer/IS Architect (Doucek et al., 2007)

\begin{tabular}{|c|c|}
\hline $\begin{array}{l}\text { Developer / IS Architect } \\
\text { Professions: } \\
\text { developer, } \\
\text { programmer, } \\
\text { tester, } \\
\text { system integrator, } \\
\text { ICT architect, } \\
\text { system development manager. }\end{array}$ & $\begin{array}{l}\text { Key knowledge: } \\
\text { - Technologies and procedures needed for design, integration and operation of appli- } \\
\text { cations. } \\
\text { - } \text { Design and development of user-friendly applications with simplified operational } \\
\text { requirements. } \\
\text { - } \text { Design of suitable technological and application architecture of IS/ICT organization. } \\
\text { Key activities: } \\
\text { - Analysis and design of ICT applications (on-line services, BI, effectiveness of busi- } \\
\text { ness processes, personal/tailored application, entertainment). } \\
\text { Database design. } \\
\text { - } \text { Pata mining. } \\
\text { - Grogramming of client, server, database and web applications. } \\
\text { - Application testing. } \\
\text { Application documentation (design, program, operational, users). } \\
\text { - } \text { Maintenance and administration of application versions } \\
\text { - Design of hardware, software and data architectures. } \\
\text { Note: Thanks to easy outsourcing these professions might be transferred to countries } \\
\text { with low labor costs - except analysts and designers of applications. }\end{array}$ \\
\hline
\end{tabular}


4. Video is a very popular format within social networks, therefore skills related to creation; editing and postproduction would be expected.

These facts are not included into this article, because this survey was only preliminary and final version of the questionnaire is distributed to respondents at this time.

\subsection{Skill Categories (Domains)}

In cooperation with the association of ICT managers (CACIO - Czech Association of CIOs), we formulated the requirements on obligatory knowledge and skills of ICT professionals, required in all the roles. We consider that they include particularly a high degree of creativity in resolving tasks, good knowledge of the English language (written and spoken), ability to work in a team and communication abilities and also, e.g., the ability to learn from practical examples. We did not determine these skills in the study.

We related the definition of obligatory knowledge and skills to the definition of knowledge domains in the sense of communicable words (pedagogical process) or practical exercises of acquired knowledge and skills. Here we defined the knowledge and skills that are required for the individual roles with various levels of necessity.

This study concentrates on 16 skill categories (based, but not limited to the respected IT curricula - Strawman curricula (Strawman, 2004) and their weight in the university graduate or employee profile.

Following ICT knowledge categories (domains) were identified for our research: MS01 - Process modeling, MS02 - Functionality and customization, MS03 - Management IS/ ICT, MS04 - Analysis and design, MS05 - Software engineering, MS06 - Data and information engineering, MS07 - IS/ ICT knowledge, MS08 - Operational excellence, MS09 Team leadership skills, MS10 - ICT market knowledge.

The main non-ICT knowledge categories (domains) were identified as following: MS11 - Organizational management methods, MS12 - Enterprise finance and economics, MS13 - Sales and marketing, MS14 - Mathematics, MS15 - Law, MS16 - Knowledge in business sectors.

We described each of these knowledge domains so that the respondents in the survey would be capable of assigning ECTS (European Credit Transfer and Accumulation System) credits obtained by the students in the subject areas to the relevant domains. The individual domains, their description and mapping between the various surveys are described, e.g., in (Maryska et al., 2012).

\subsection{Knowledge Levels}

In order to compare the "amount" of knowledge devoted to each skill category by university program or by business requirements non-linear scale was defined as follows on Table 2:
Table 2: Levels of Knowledge

\begin{tabular}{|c|l|}
\hline Level & Description \\
\hline 0 & No knowledge. \\
\hline 1 & $\begin{array}{l}\text { Overview (relevant to } \mathbf{1 - 2} \text { credits or intensive } \\
\text { training days). }\end{array}$ \\
\hline 2 & $\begin{array}{l}\text { Basic orientation and terminology (relevant to } \\
\mathbf{3 - 5} \text { credits or intensive training days). }\end{array}$ \\
\hline 3 & $\begin{array}{l}\text { Good orientation and basic practical skills } \\
\text { (relevant to 6-20 credits or intensive training } \\
\text { days). }\end{array}$ \\
\hline 4 & $\begin{array}{l}\text { Good orientation and good practical skills } \\
\text { (relevant to 21-40 credits or intensive training } \\
\text { days). }\end{array}$ \\
\hline 5 & $\begin{array}{l}\text { Highest knowledge quality and advanced } \\
\text { practical skills (relevant to } \mathbf{4 1} \text { and more cred- } \\
\text { its or intensive training days). }\end{array}$ \\
\hline
\end{tabular}

On the basis of long discussions with representatives of universities and enterprises in the ICT area, we decided to employ this scale also for questioning companies. For companies, we replaced the number of ECTS credits for economic entities by the more comprehensible term "number of days of training". The recalculation mechanism was chosen as the ratio 1 ECTS credit $=1$ day of training. We arrived at the equivalence 1 ECTS credit equals one day of training, i.e. 8 hours, after analyzing the teaching plans for subjects in informatics in the Czech Republic, Germany, Austria and Poland. This corresponds to direct effective teaching.

\subsection{Knowledge Profiles and Their Distances}

Set of knowledge levels for each of the skill categories was defined in this research as "knowledge profile" and used to compare the requirements of business with the supply of universities.

The distance between the knowledge profiles in our research was analyzed. Distance between university knowledge profile A and business knowledge profile B is expressed by the number of additional intensive training days required for the graduate with knowledge profile A to fulfill the minimal requirements of profile $\mathrm{B}$. The smaller the distance the "cheaper" the graduate of university for the relevant ICT role in business is.

We applied the modified method of distance from ideal variant for comparison between $\mathrm{A}$ and $\mathrm{B}$ profiles.

where

$$
\mathrm{D}(\mathrm{a})=\mathrm{d}(\mathrm{A}, \mathrm{B}) \text {, }
$$

$\mathrm{d}$ is the function of the distance,

vector A contents evaluation of each knowledge domain of academic profile,

vector B contents evaluation of each knowledge domain of business profile for each ICT business role. 
Function of the distance is calculated for each knowledge domain by following metric:

$$
\begin{array}{ll}
d\left(A_{i}, B_{i}\right)=0, & \text { for } A_{i}>=B_{i}, \\
d\left(A_{i}, B_{i}\right)=B_{i}-A_{i} & \text { for } A_{i}<B_{i} .
\end{array}
$$

The aggregated distance between academic knowledge profile and ICT business role profile is then calculated as $\mathrm{D}(\mathrm{a})$ $=\Sigma \mathrm{d}_{\mathfrak{i}}\left(\mathrm{A}_{\mathrm{i}}, \mathrm{B}_{\mathfrak{i}}\right)$ for all $\mathrm{i}=1$, number of domains (16) and its interpretation is number of training days, that must be invested into the new enrolled ICT professional. Following discussions with representatives of enterprises and professional companies, we considered that 60 days of training is an acceptable limit to the number of days of extra training (acceptable distance), where the graduate is still not too expensive for the economic entity.

\subsection{Data collection}

Survey and data collection were performed in two main streams - the first one were the universities and the second one the business units in the Czech Republic. The questions were based on the consult with experts on questionnaires surveys, creative applying the rules thus defined, based on theoretical principals for indirect sampling (Lavalleé, 2007; Thompson, 2012).

There were used similar questionnaires for both realized surveys divided into two sections:

- Identifications of the respondent's unit (university or company).

- Seventeen questions on knowledge level (scale of this knowledge level is presented in Table 2) provided by universities/requested by companies (companies answers questions on knowledge for all defined ICT roles).

\section{口 $\quad$ For universities}

- Number of students studying defined study program (number of new (entrance) students, number of all students, number of graduates students)

- Method for evaluation students that are studying defined ICT related study program (ECTS credits, credits of direct lectures per semester etc.).

- Sum of all credits for study subjects which have to be fulfilled in this study program.

- Knowledge domains (16 knowledge categories, domains) that are evaluated as a sum of credits that are lectured in defined ICT related study programs.
Number of all credits represented by total sum of credits in each knowledge domain. These credits were divided into two groups: obligatory and optional.

\section{口 For business units}

- Sum of expected/required knowledge in each domain expressed in level of appropriate knowledge (Table $2)$.

Questionnaire was based primarily on closed questions, but there was a place for written text in which respondent could provide additional information about the study field, knowledge provided to students and other to the survey relevant facts.

\section{Survey among Businesses}

All active economic subjects in the Czech Republic on the end of 2005 (the first survey was held in 2006). According to data of the Czech Statistical Office, there were 1,266,336 subjects of various size and main economic activity.

Size of entity: According to the number of employees, 6 categories were used: $0,1-9,10-49,50-249,250$ - 999, 1,000 and more.

Sector of main economic activity: There are 17 main sectors in Industrial Classification of Economic Activities of the Czech Statistical Office. According to the requirements on information technologies, these sectors were coded into 3 categories: sectors with the lowest requirements (LIT), sectors with the middle requirements (MIT) and sectors with the highest requirements (HIT).

Method of sampling from the population: According to the size of subject and the category of its economic activity, the population was grouped into 18 subpopulations. Afterwards, stratified sampling was applied. There are no homogenous subgroups in the population. As can be seen in Table 3, their size varies much. Because of the number of employees the variation of number of IT workers in subject is certainly very heterogeneous, too. Optimal allocation requires knowledge of this variability (it was un-known). So, this heterogeneity was taken into account at least in the following way: the sampling fraction was higher in strata with more employees and in sectors with the higher requirements on information technologies. The interviewing methods used were CAWI (Computer Aided Web Interviewing) and CATI (Computer-Assisted Personal Interviewing). Realized sample size was 1,002 (Table 4).

Table 3: Sector Map for Business Units in the Czech Republic (2005)

\begin{tabular}{|l|c|r|r|r|r|r|r|}
\hline & $\mathbf{0}$ & $\mathbf{1 - 9}$ & $\mathbf{1 0 - 4 9}$ & $\mathbf{5 0 - 2 4 9}$ & $\mathbf{2 5 0}-\mathbf{9 9 9}$ & $\mathbf{1 , 0 0 0}+$ & Total \\
\hline LIT & 263,289 & 49,914 & 14,270 & 4,317 & 369 & 87 & 332,246 \\
\hline MIT & 697,380 & 138,555 & 28,014 & 6,217 & 1,164 & 182 & 871,512 \\
\hline HIT & 49,851 & 9,590 & 2,216 & 710 & 170 & 41 & 62,578 \\
\hline Total & $1,010,520$ & 198,059 & 44,500 & 11,244 & 1,703 & 310 & $1,266,336$ \\
\hline
\end{tabular}


Table 4: Structure of the Observed Sample 2006

\begin{tabular}{|l|c|c|c|c|c|c|c|}
\hline & $\mathbf{0}$ & $\mathbf{1 - 9}$ & $\mathbf{1 0 - 4 9}$ & $\mathbf{5 0 - 2 4 9}$ & $\mathbf{2 5 0}-\mathbf{9 9 9}$ & $\mathbf{1 , 0 0 0 +}$ & Total \\
\hline LIT & 56 & 28 & 28 & 28 & 37 & 16 & 193 \\
\hline MIT & 56 & 56 & 56 & 56 & 71 & 36 & 331 \\
\hline HIT & 56 & 110 & 160 & 122 & 26 & 4 & 478 \\
\hline Total & 168 & 194 & 244 & 206 & 134 & 56 & 1,002 \\
\hline
\end{tabular}

The structure of the sample for the second survey in 2010 was changed. The main changes were realized in structure of the sample, as the categories 0, 1-9 were removed from the sample (based on the analysis of the 2006 results and on the recommendation of the Czech Statistical Office experts), and the last two categories 250-999 and 1,000+ were joined into the category $250+$. The second survey between business sectors was realized in 2010 on the sample size of 1,011 companies (Table 5).

Table 5: Structure of the Observed Sample 2010

\begin{tabular}{|l|r|r|r|r|}
\hline & $\mathbf{1 0 - 4 9}$ & $\mathbf{5 0 - 2 4 9}$ & $\mathbf{2 5 0}+$ & Total \\
\hline LIT & 45 & 46 & 44 & 135 \\
\hline MIT & 57 & 474 & 98 & 629 \\
\hline HIT & 66 & 142 & 39 & 247 \\
\hline Total & 168 & 662 & 181 & 1,011 \\
\hline
\end{tabular}

Both of surveys were realized by the private research company which disposes of needed sample of companies which guarantee comparability of results from both surveys. Although the samples of companies in both surveys were different numbers of companies in each cluster were similar in both surveys.

\section{Variables:}

a) Number of IT employees in 2010 in the following structure: business analyst, IT manager, IT salesperson (dealer), architect of information networks, administrator and lector. Expected number of IT workers for some following years. This data are not presented in the paper.

b) Knowledge requirements on particular professional positions: there were 16 skill categories defined (thus, 16 ordinal variables with values 0 - "no knowledge $(0$ training days)" .. . 5 - "highest knowledge (more than 41 training days)" (Table 2).

c) Classification variables: number of employees, sector of main economic activity, requirements of the sector on information technologies, IT supplier or customer, national or external owner.

\section{Knowledge requirements:}

With respect to the nature of variables, medians were used. To compare different professional positions and differ- ent skill categories, box plots (for sampling distributions) and scatter plots (for medians) were used.

All collected data were processed using cluster analysis method built in MS SQL Server version 2008.

\section{Survey among Universities}

The surveyed population:

All Higher Education Institutions (HEIs) providing university level ICT related study programs based on evidence of the Czech Ministry of Education. There were identified 71 faculties (376 study programs) in that evidence. To all of these subjects a questionnaire was sent via Internet and they were asked to fill it for each IT related study program they provide. The response rate is presented on the following Table 6 .

Table 6: Response Rate for Survey 2011

\begin{tabular}{|l|c|c|c|}
\hline & Universities & Faculties & Specializations \\
\hline Identified & 31 & 71 & 376 \\
\hline Response & 21 & 29 & 196 \\
\hline $\begin{array}{l}\text { Response } \\
\text { rate }\end{array}$ & $68 \%$ & $41 \%$ & $52 \%$ \\
\hline
\end{tabular}

\section{Method of sampling data from the population:}

As the whole population was surveyed no sampling method had to be used. Missing quantitative data (number of enrolled, number of students, number of graduates) from notreplying subjects have been reconstructed from the official resources of the Czech Ministry of Education. Missing qualitative data (number of credits devoted to each skill category) were not reconstructed and these faculties were excluded from final results. These were marked as "not classified" segment.

\section{Variables:}

a) Number of students, number of enrolled (new entrants to the study program each year) number of graduates in the school years 2000 to 2009 and expected numbers for some following years. These data are not presented in this paper.

b) Number of credits devoted to each of 16 skill categories defined.

c) Classification variable: level of study program - bachelor, master (2 year), master (5 year; these are the "pre Bologna" programs ending in 2006 or 2007 school years). 
In order to identify study programs with common patterns (from the perspective of the knowledge provided to their graduates) we have used cluster analysis (with the expectation-maximization algorithms). ICT programs were classified into eight segments (four for bachelor and four for master programs). To express the location of particular obtained knowledge in each segment, medians were used again. The star charts ("spider" charts) were used to compare the knowledge obtained and required in particular skill categories for each professional position. The concept of distance (described in previous chapter) was used as a metric of relevance of appropriate study program and business requirements on appropriate ICT role. This metric then shows the number of additional training days for each business role. Only these graduates that have distance less than 60 training days are acceptable for business positions.

Note: "1 credit = 1 intensive training day" comparison ratio was used. This relation was set up after long discussions with ICT managers and experts from businesses. Six ECST credits are represented by 52 direct teaching hours in thirteen weeks semester. It represents 8.7 teaching hours on 1 ECTS credit. We spend approximately 0.7 hour per credit of teaching time for organizing course and for public holidays in Czech conditions.

Both of surveys were realized by the research team of the University of Economics in Prague. Although the survey was realized as census the structures of responses were different. We have identified reasons as follows: new study fields were newly established and some of existing study fields was dissolved and not all of appealed universities sent to us filled up questionnaires.

\subsection{Data processing}

In relation to the further performed statistical analysis of the answers of the respondents in the survey, we evaluated the variables mainly by the statistical method of the median. We employed the technique of box plots (for sampling distributions) and scatter plots (for medians) to compare the differences in the individual professional roles and differences in knowledge categories.

The data obtained from respondents were processed by the methods and instruments of cluster analysis with support from the instruments of the MS SQL Server 2008 R/2 platform. In the context of the principles of cluster analysis, it should be added that we used EM (Expectation-Maximization) algorithms (Bilmes, 1998; MacLennan et al., 2009).

\section{Results}

\subsection{Business Units}

\section{Data characteristics}

There were analyzed 1425 companies` answers from 1011 companies in the Czech Republic which were selected according to the structure of the market in the Czech Republic. Descriptive statistics of the data collected from companies are presented in Table 7. Each of selected companies can provide answers to 0-7 ISC roles.

Knowledge is required on level 3 in majority of ICT knowledge domain. Exception is created by knowledge domain IS/ICT knowledge and Operational excellence which are on the level 4 (3.5).

We have found different result in non-ICT knowledge domains. There are only three knowledge domains (MS09 Team leadership skills, MS10 ICT market knowledge and MS16 Knowledge in business sectors) required on the level 3 and other non-ICT knowledge domains are required on level 2.

\section{Knowledge requirements}

The following Table 8 presents business requirements on the defined ICT roles. This table describes in higher detail previous Table 7. Data in following table are based on the median of knowledge required for defined role by all analyzed companies.

We can say that in general companies requires ICT knowledge at least on the level 3 and in selected roles also on the level 4 (especially for the role Enterprise Architect). From our point of view are interesting results for role Lecturer whose knowledge are required on the level 3 and in knowledge domains MS03 Management IS/ICT and MS05 Software engineering only on the level 2 .

On contrary the highest requirements are demanded of the role Enterprise architect. All knowledge domains are required on the level 4 and only knowledge domain MS06 Data and information engineering is required on the level 3.

Similar results as in Table 8 are displayed in the Table 9. Table 9 describes business requirements on defined roles but in additional training days which have to be invested into the new employee without any knowledge in the knowledge domain (previous Table 8 was based on required level of knowledge).

\subsection{Universities}

\section{Data characteristics}

There were analyzed data from study programs and specializations (196) with general orientation on informatics in the Czech Republic. Descriptive statistics of the data collected from universities are presented in Table 10.

\section{Bachelor Level of Education}

Some results of our survey (2010) in area of knowledge and skills that offers main education stream ICT are presented on different level of university graduates in ICT related study programs. The first part of our survey was focused on bachelor study level. Knowledge profiles of bachelor segment are shown on Figure 2.

There were identified following results for Bachelor graduates on the Czech universities - Figure 2. Data were split by clustering method in four clusters. The Bc-A11 cluster offers good knowledge in software engineering, data and information engineering and ICT knowledge. Graduates in this cluster are specialized for entering labor market immediately in business roles Administrator, Analyst, Manager ICT and Lector (Table 11). Bc-B11 cluster is one of the weakest 
Table 7: Descriptive Statistics of Collected Data (Companies Aggregated)

\begin{tabular}{|c|c|c|c|c|c|c|c|c|c|}
\hline & \multicolumn{9}{|c|}{$n=1425$} \\
\hline & Avg. & Med. & Mod. & Max. & Min. & $\boldsymbol{\sigma}$ & $\sigma^{2}$ & $\delta$ & $\tau$ \\
\hline MS01 Process modeling & 2.64 & 3.00 & 3.00 & 5.00 & 0.00 & 1.40 & 1.96 & -0.14 & -0.81 \\
\hline MS02 Functionality and customization & 2.96 & 3.00 & 3.00 & 5.00 & 0.00 & 1.22 & 1.48 & -0.49 & -0.23 \\
\hline MS03 Management IS/ICT & 2.94 & 3.00 & 3.00 & 5.00 & 0.00 & 1.32 & 1.73 & -0.35 & -0.45 \\
\hline MS04 Analysis and design & 3.02 & 3.00 & 4.00 & 5.00 & 0.00 & 1.30 & 1.68 & -0.53 & -0.24 \\
\hline MS05 Software engineering & 2.71 & 3.00 & 3.00 & 5.00 & 0.00 & 1.32 & 1.74 & -0.32 & -0.61 \\
\hline MS06 Data and information engineering & 2.94 & 3.00 & 3.00 & 5.00 & 0.00 & 1.20 & 1.44 & -0.21 & -0.26 \\
\hline MS07 IS/ICT knowledge & 3.49 & 4.00 & 4.00 & 5.00 & 0.00 & 1.12 & 1.26 & -0.74 & 0.42 \\
\hline MS08 Operational excellence & 3.27 & 3.50 & 4.00 & 5.00 & 0.00 & 1.28 & 1.64 & -0.50 & -0.49 \\
\hline MS09 Team leadership skills & 2.74 & 3.00 & 3.00 & 5.00 & 0.00 & 1.37 & 1.86 & -0.29 & -0.67 \\
\hline MS10 ICT market knowledge & 2.80 & 3.00 & 3.00 & 5.00 & 0.00 & 1.26 & 1.60 & -0.26 & -0.47 \\
\hline MS11 Organizational management methods & 2.43 & 2.00 & 3.00 & 5.00 & 0.00 & 1.37 & 1.88 & -0.02 & -0.87 \\
\hline MS12 Enterprise finance and economics & 2.19 & 2.00 & 2.00 & 5.00 & 0.00 & 1.29 & 1.66 & 0.02 & -0.56 \\
\hline MS13 Sales and marketing & 2.06 & 2.00 & 2.00 & 5.00 & 0.00 & 1.28 & 1.64 & 0.11 & -0.72 \\
\hline MS14 Mathematics & 2.24 & 2.00 & 2.00 & 5.00 & 0.00 & 1.32 & 1.73 & 0.09 & -0.69 \\
\hline MS15 Law & 2.36 & 2.00 & 2.00 & 5.00 & 0.00 & 1.30 & 1.68 & 0.12 & -0.72 \\
\hline MS16 Knowledge in business sectors & 2.95 & 3.00 & 3.00 & 5.00 & 0.00 & 1.37 & 1.87 & -0.35 & -0.60 \\
\hline
\end{tabular}

Table 8: Business Requirements in Levels of Knowledge - Median

\begin{tabular}{|c|c|c|c|c|c|c|c|}
\hline Knowledge domain/Business role & Developer & Administrator & Lecturer & Sales & Manager & $\begin{array}{c}\text { Business } \\
\text { Analyst }\end{array}$ & $\begin{array}{c}\text { Enterprise } \\
\text { Architect }\end{array}$ \\
\hline MS01 Process modeling & 3 & 2 & 3 & 3 & 3 & 3 & 4 \\
\hline $\begin{array}{l}\text { MS02 Functionality and customiza- } \\
\text { tion }\end{array}$ & 3 & 3 & 3 & 3 & 3 & 3 & 4 \\
\hline MS03 Management IS/ICT & 3 & 3 & 2 & 3 & 3 & 3 & 4 \\
\hline MS04 Analysis and design & 4 & 3 & 3 & 3 & 3 & 3 & 4 \\
\hline MS05 Software engineering & 4 & 3 & 2 & 2 & 3 & 3 & 4 \\
\hline $\begin{array}{l}\text { MS06 Data and information engi- } \\
\text { neering }\end{array}$ & 4 & 3 & 3 & 3 & 3 & 3 & 3 \\
\hline MS07 IS/ICT knowledge & 4 & 4 & 3 & 3 & 4 & 3 & 4 \\
\hline MS08 Operational excellence & 3 & 3 & 3 & 3 & 4 & 3 & 4 \\
\hline MS09 Team leadership skills & 3 & 3 & 3 & 3 & 3 & 3 & 3 \\
\hline MS10 ICT market knowledge & 3 & 3 & 2 & 4 & 3 & 3 & 3 \\
\hline $\begin{array}{l}\text { MS11 Organizational management } \\
\text { methods }\end{array}$ & 2 & 2 & 3 & 3 & 3 & 3 & 3 \\
\hline $\begin{array}{l}\text { MS12 Enterprise finance and eco- } \\
\text { nomics }\end{array}$ & 2 & 2 & 2 & 3 & 3 & 3 & 3 \\
\hline MS13 Sales and marketing & 2 & 2 & 2 & 4 & 2 & 2 & 3 \\
\hline MS14 Mathematics & 3 & 2 & 2 & 2 & 2 & 3 & 3 \\
\hline MS15 Law & 2 & 2 & 2 & 3 & 2 & 2 & 3 \\
\hline MS16 Knowledge in business sectors & 3 & 3 & 3 & 4 & 3 & 3 & 4 \\
\hline
\end{tabular}


Table 9: Business Requirements in Training Days

\begin{tabular}{|l|c|c|c|c|c|c|c|}
\hline Knowledge domain/Business role & Developer & $\begin{array}{c}\text { Adminis- } \\
\text { trator }\end{array}$ & Lecturer & Sales & Manager & $\begin{array}{c}\text { Business } \\
\text { Analyst }\end{array}$ & $\begin{array}{c}\text { Enterprise } \\
\text { Architect }\end{array}$ \\
\hline MS01 Process modeling & 13 & 4 & 13 & 13 & 13 & 13 & 31 \\
\hline $\begin{array}{l}\text { MS02 Functionality and } \\
\text { customization }\end{array}$ & 13 & 13 & 13 & 13 & 13 & 13 & 31 \\
\hline MS03 Management IS/ICT & 13 & 13 & 13 & 13 & 13 & 13 & 31 \\
\hline MS04 Analysis and design & 31 & 13 & 13 & 13 & 13 & 13 & 31 \\
\hline MS05 Software engineering & 31 & 13 & 4 & 4 & 13 & 13 & 31 \\
\hline $\begin{array}{l}\text { MS06 Data and information } \\
\text { engineering }\end{array}$ & 31 & 13 & 13 & 13 & 13 & 13 & 13 \\
\hline MS07 IS/ICT knowledge & 31 & 31 & 13 & 13 & 31 & 13 & 31 \\
\hline MS08 Operational excellence & 13 & 13 & 13 & 13 & 31 & 13 & 31 \\
\hline MS09 Team leadership skills & 13 & 13 & 13 & 13 & 13 & 13 & 13 \\
\hline MS10 ICT market knowledge & 13 & 13 & 4 & 31 & 13 & 13 & 13 \\
\hline $\begin{array}{l}\text { MS11 Organizational management } \\
\text { methods }\end{array}$ & 4 & 4 & 13 & 13 & 13 & 13 & 13 \\
\hline $\begin{array}{l}\text { MS12 Enterprise finance and } \\
\text { economics }\end{array}$ & 4 & 4 & 4 & 13 & 13 & 13 & 13 \\
\hline MS13 Sales and marketing & 4 & 4 & 4 & 31 & 4 & 4 & 13 \\
\hline MS14 Mathematics & 14 & 4 & 4 & 4 & 4 & 13 & 13 \\
\hline MS15 Law & 4 & 4 & 4 & 13 & 4 & 4 & 13 \\
\hline MS16 Knowledge in business sectors & 14 & 13 & 13 & 31 & 13 & 13 & 31 \\
\hline
\end{tabular}

Table 10: Descriptive Statistics of Collected Data (Bachelor and Master Study Programs Aggregated)

\begin{tabular}{|l|c|c|c|c|c|c|c|c|}
\hline \multirow{2}{*}{ Knowledge Domain } & \multicolumn{9}{|c|}{$\mathbf{n}=\mathbf{1 9 6}$} \\
\cline { 2 - 9 } & Avg. & Med. & Mod. & Max. & Min. & $\boldsymbol{\sigma}$ & $\boldsymbol{\sigma}^{\mathbf{2}}$ & $\boldsymbol{\delta}$ \\
\hline MS01 Process modeling & 1.62 & 2 & 3 & 0 & 1.31 & 1.71 & -0.282 & -1.687 \\
\hline MS02 Functionality and customization & 1.45 & 2 & 3 & 0 & 1.46 & 1.69 & 0.047 & -1.993 \\
\hline MS03 Management IS/ICT & 1.80 & 2 & 4 & 0 & 1.34 & 1.74 & -0.390 & -1.432 \\
\hline MS04 Analysis and design & 1.82 & 2 & 3 & 0 & 1.36 & 1.73 & -0.506 & -1.616 \\
\hline MS05 Software engineering & 2.75 & 3 & 5 & 0 & 1.52 & 2.58 & -0.887 & -0.519 \\
\hline MS06 Data and information engineering & 2.80 & 3 & 5 & 0 & 1.68 & 2.47 & -0.675 & -0.828 \\
\hline MS07 IS/ICT knowledge & 3.38 & 3 & 5 & 0 & 1.57 & 2.73 & -0.921 & 0.273 \\
\hline MS08 Operational excellence & 1.92 & 3 & 4 & 0 & 1.38 & 1.92 & -0.551 & -1.543 \\
\hline MS09 Team leadership skills & 1.88 & 3 & 4 & 0 & 1.45 & 1.91 & $-0,411$ & -1.614 \\
\hline MS10 ICT market knowledge & 1.51 & 1 & 3 & 0 & 1.39 & 1.56 & 0.019 & -1.899 \\
\hline MS11 Organizational management methods & 1.40 & 2 & 4 & 0 & 1.41 & 1.75 & 0.142 & -1.806 \\
\hline MS12 Enterprise finance and economics & 2.32 & 2 & 5 & 0 & 1.71 & 2.45 & 0.014 & -1.101 \\
\hline MS13 Sales and marketing & 1.22 & 2 & 3 & 0 & 1.26 & 1.27 & 0.212 & -1.704 \\
\hline MS14 Mathematics & 3.05 & 3 & 5 & 0 & 1.66 & 2.63 & -0.770 & -0.316 \\
\hline MS15 Law & 1.80 & 2 & 3 & 0 & 1.11 & 1.29 & -0.517 & -1.049 \\
\hline MS16 Knowledge in business sectors & 0.25 & 0 & 2 & 0 & 0.66 & 0.50 & 2.349 & 3.630 \\
\hline
\end{tabular}




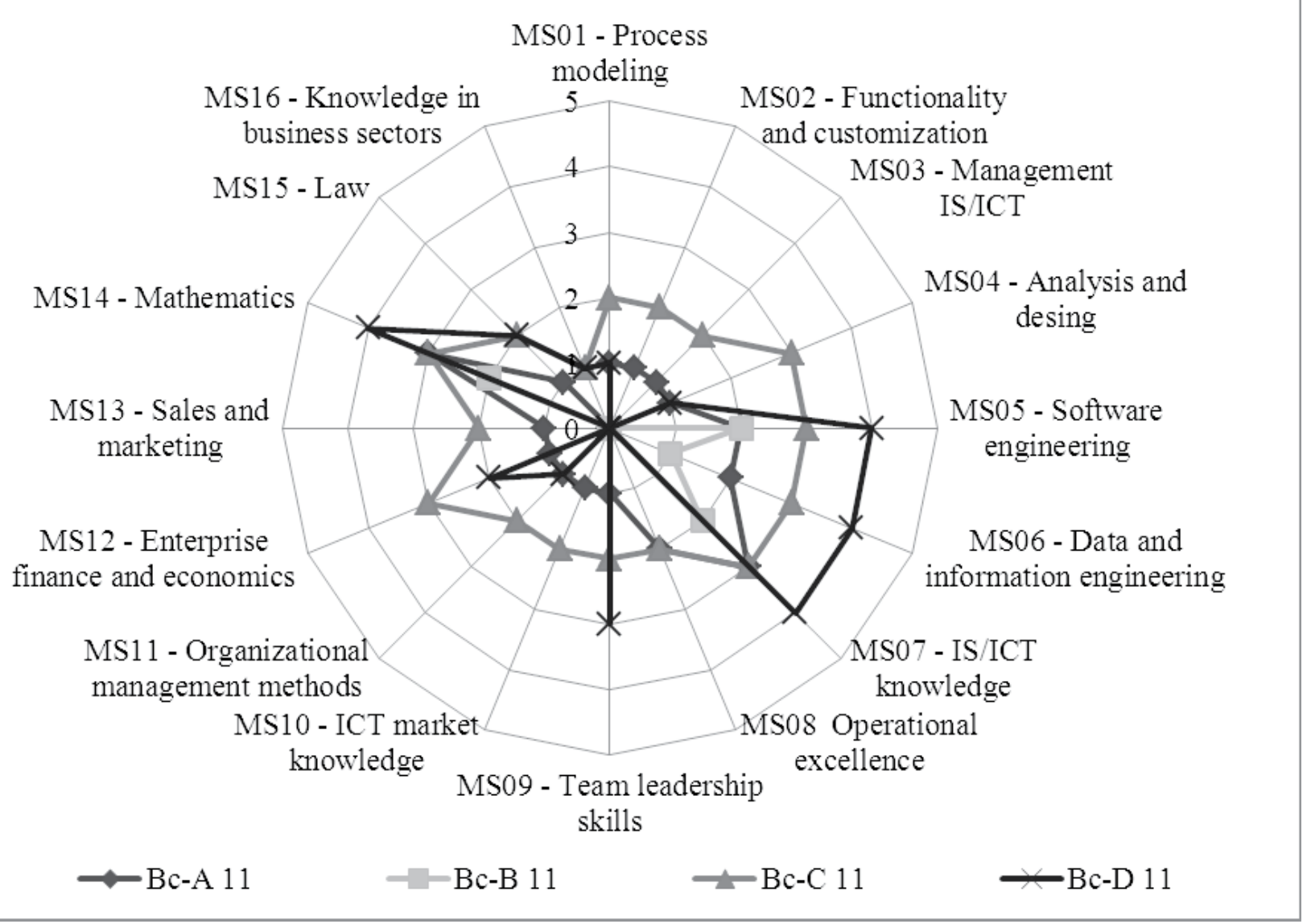

Figure 2: Bachelor Studies Knowledge Profiles, Obligatory and Optionally Courses (Source: authors)

clusters with accent on ICT knowledge, data and information engineering and mathematics. Other skills and knowledge are missing in the scope of education process. Knowledge of this cluster does not offer knowledge for any business role (Table 11). Optionally courses do not help to change this fact (Table 12). Bc-C11 cluster offers complex common education in area of business informatics without strong specialization. Graduates of this cluster could be linked with business roles Administrator, Analyst, Developer, Manager ICT and Lector (Table 11). Optionally courses add to this role position Dealer (Table 12). Cluster Bc-D11 offers very good education in mathematics and its topic seems to be in software, data and information engineering and ICT knowledge. Graduates of this sector fit very well to business requirements on roles Administrator, Analyst, and Lector (Table 11). Subscribing optionally course enlarge their acceptance for other business roles - Developer and Manager (Table 12).

Optionally courses offer enlargement of ICT knowledge profile. Differences caused by additional optionally courses are visible as differences between appropriate cells in Table 8 and Table 12.

Master and Bachelor Level of Education - Aggregated

There are presented (Figure 3) results of analysis of aggregated knowledge in bachelor and in consequential master study programs (Mgr5) in this chapter. The majority of bachelors continue to master study programs at in the Czech Republic the same faculty, therefore such aggregation is relevant in this context.

There were identified four clusters in this segment of ICT related study programs graduates. Cluster Mgr-5A 11 produces graduates with basic skills in knowledge domains -MS01 Process modeling, MS02 Functionality and customization, MS03 Management IS/ICT, MS08 Operational Excellence, MS09 Team leadership skills, MS11 Organizational management methods and MS13 Sales and marketing., Good orientation and basic practical skills are taught in following knowledge domains - MS04 Analysis and design, MS05 Software engineering, MS10 ICT market knowledge, MS12 Enterprise finance and economics and MS15 Law. Knowledge domains MS06 Data and information engineering, MS07 IS/ ICT knowledge and MS14 Mathematics provide knowledge on other highest knowledge levels. Cluster Mgr5-B 11 offers very little of ICT oriented knowledge to its graduates. Basic knowledge is taught in domain MS07 IS/ICT knowledge, MS05 Software engineering, MS06 Data and information engineering and MS14 Mathematics. There are not covered by taught knowledge other domains in this cluster. Graduates of this cluster do not fit to any of identified roles (Table 13) and work hypothesis is that they are leaving tertiary education either on position programmer or they are enter the working process as qualified ICT users and optionally courses do 
Table 11: Bachelor Knowledge Profiles - Obligatory Knowledge (The bold written values are acceptable for business practice)

\begin{tabular}{|l|c|c|c|c|c|c|c|}
\hline Cluster & Administrator & Analyst & Architect & Dealer & Developer & Manager & Lector \\
\hline Bc-A 11 & $\mathbf{4 3}$ & $\mathbf{4 1}$ & 148 & 89 & 77 & $\mathbf{6 3}$ & $\mathbf{3 5}$ \\
\hline Bc-B 11 & 80 & 79 & 194 & 127 & 122 & 104 & 70 \\
\hline Bc-C 11 & $\mathbf{3 4}$ & $\mathbf{2 7}$ & 129 & 70 & $\mathbf{6 5}$ & $\mathbf{5 1}$ & $\mathbf{2 4}$ \\
\hline Bc-D 11 & $\mathbf{4 7}$ & $\mathbf{5 5}$ & 164 & 104 & 80 & $\mathbf{7 0}$ & $\mathbf{4 7}$ \\
\hline
\end{tabular}

Table 12: Bachelor Knowledge Profiles - Obligatory and Optionally Knowledge (The bold written values are acceptable for business practice)

\begin{tabular}{|l|c|c|c|c|c|c|c|}
\hline Cluster & Administrator & Analyst & Architect & Dealer & Developer & Manager & Lector \\
\hline Bc-A 11 & $\mathbf{3 7}$ & $\mathbf{3 6}$ & 139 & 83 & 67 & $\mathbf{5 6}$ & $\mathbf{3 1}$ \\
\hline Bc-B 11 & 76 & 79 & 190 & 127 & 118 & 100 & 70 \\
\hline Bc-C 11 & $\mathbf{2 3}$ & $\mathbf{1 7}$ & 110 & $\mathbf{5 9}$ & $\mathbf{5 0}$ & $\mathbf{3 9}$ & $\mathbf{1 5}$ \\
\hline Bc-D 11 & $\mathbf{3 6}$ & $\mathbf{4 3}$ & 140 & 93 & $\mathbf{5 8}$ & $\mathbf{5 8}$ & $\mathbf{3 8}$ \\
\hline
\end{tabular}

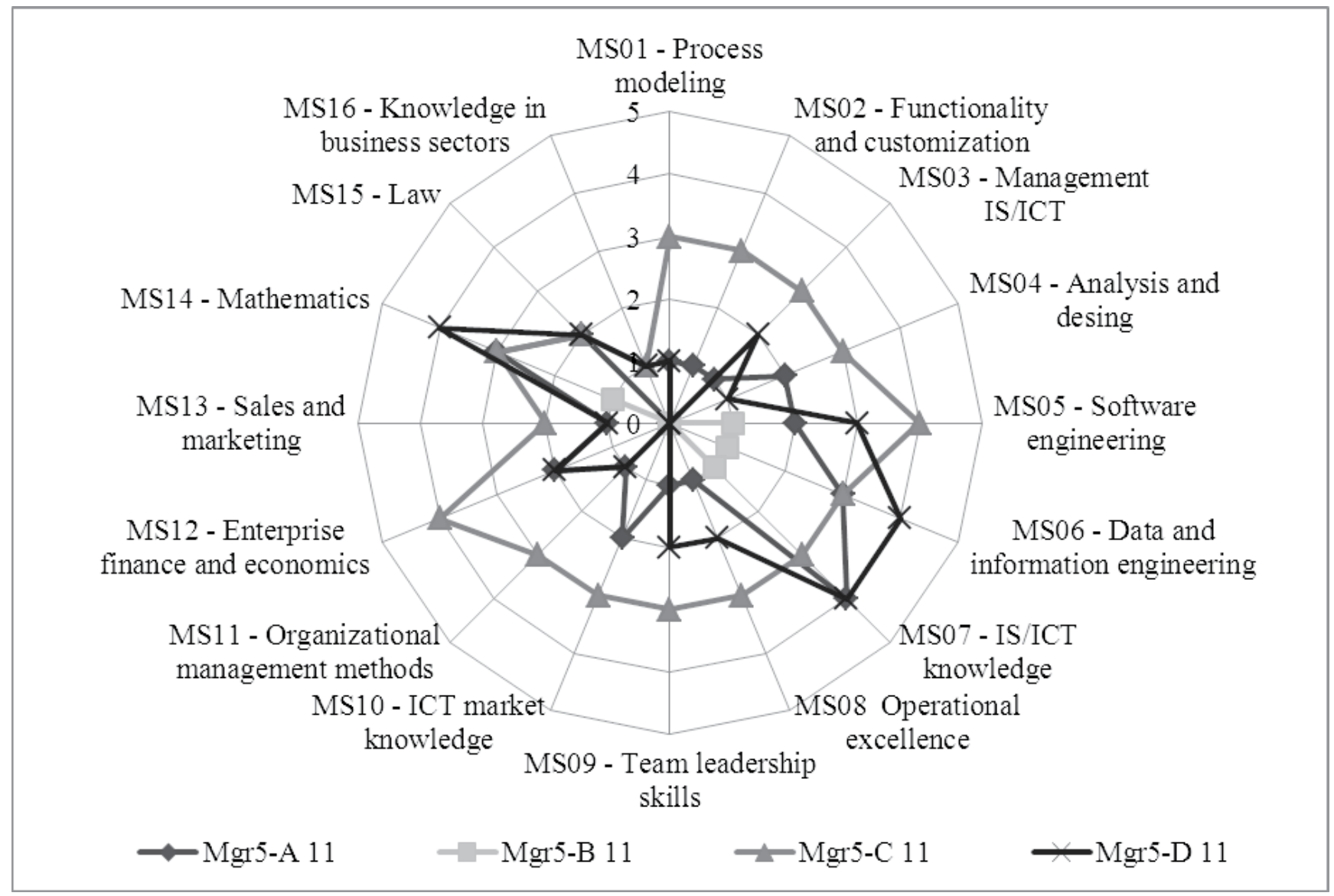

Figure 3: Bachelor and Master Studies Knowledge Profiles, Obligatory and Optionally Courses (Source: authors) 
not help them get enough knowledge for ICT business roles (Table 13). Graduates of the cluster Mgr5-C 11 can get very good education in business informatics. Their knowledge profile is based on good orientation and basic practical skills in domains MS01 Process modeling, MS02 Functionality and customization, MS03 Management IS/ICT, MS04 Analysis and design, MS06 Data and information engineering, MS07 IS/ICT knowledge, MS08 Operational excellence, MS09 Team leadership skills, MS10 ICT market knowledge, MS11 Organizational management methods and MS14 Mathematics. Good orientation and good practical skills are characteristic for domains MS05 Software engineering and MS12 Enterprise finance and economics. Graduates of this cluster do fit very well to business roles Administrator, Analysts, Developer, Manager of ICT and Lector (Table 13). Optionally courses enlarge knowledge in all business roles and enrich portfolio of accepted business roles for the role of Dealer. Mgr5-D 11 graduates get basic orientation in knowledge domains MS03 Management IS/ICT, MS08 Operational excellence, MS09 Team leadership skills, MS12 Enterprise finance and economics and MS15 Law. Good orientation and good practical skills are in domains MS05 Software Engineering, MS06 Data and information engineering, MS07 IS/ICT knowledge and MS14 Mathematics. They mostly fit to business roles Administrator, Analyst and Lectors. Optionally courses enrich portfolio for business roles Developer and Manager (Table 14).

\section{Conclusions}

Immediate results of data evaluation of the ICT education supply side in the Czech Republic study programs are:

- ICT oriented study programs significantly differ in the level of knowledge provided to the student.
- There is no direct relationship among the specific study program and specific ICT role. Some study programs form excellent background for any of the defined ITC roles, others are not useful for any of them.

- Graduate bachelors in the Czech Republic do not have sufficient knowledge spectrum to enter into business on leading positions without additional training. They are too "expensive" for further education in companies. It also depicts the situation in the Czech Republic, where only about one third of ICT graduates do not continue with the Master studies. Bachelor study programs are then formulated not as standalone, but rather as prerequisites for the Master studies.

- There are not enough relevant students and graduates with required ICT knowledge profiles in the Czech Republic. Especially roles as Information System Architect (similar conclusions are mentioned in (Gala and Jandos, 2010)) and Dealer - Business Person in ICT Products and Services are not covered by the actual ICT education system in Czech Republic.

- There are significant differences in answers we receive from companies and universities. Companies in general require knowledge on lower level in year 2011 than in year 2006. Universities in general provides the same level of knowledge in both surveys but these knowledge is provided in better structure in the relation to requirement of business companies (in detail for example: (Maryska et al, 2012)).

- Differences in answers for university ICT oriented study programs in 2005 and 2011 are presented in Table 15. Changes are presented with arrows in the last column of the table.

Table 13: Bachelor and Master Aggregated Knowledge Profiles - Obligatory Knowledge (The bold written values are acceptable for business practice)

\begin{tabular}{|l|c|c|c|c|c|c|c|}
\hline Cluster & Administrator & Analyst & Architect & Dealer & Developer & Manager & Lector \\
\hline Mgr5-A 11 & $\mathbf{4 8}$ & $\mathbf{5 1}$ & 158 & 99 & 85 & 70 & $\mathbf{4 5}$ \\
\hline Mgr5-B 11 & 90 & 87 & 211 & 133 & 139 & 114 & 76 \\
\hline Mgr5-C 11 & $\mathbf{2 6}$ & $\mathbf{2 0}$ & 116 & 67 & $\mathbf{4 6}$ & $\mathbf{4 3}$ & $\mathbf{1 7}$ \\
\hline Mgr5-D 11 & $\mathbf{4 6}$ & $\mathbf{5 4}$ & 158 & 102 & 78 & $\mathbf{6 4}$ & $\mathbf{4 5}$ \\
\hline
\end{tabular}

Table 14: Bachelor and Master Aggregated Knowledge Profiles - Obligatory and Optionally Knowledge (The bold written values are acceptable for business practice)

\begin{tabular}{|l|c|c|c|c|c|c|c|}
\hline Cluster & Administrator & Analyst & Architect & Dealer & Developer & Manager & Lector \\
\hline Mgr5-A 11 & $\mathbf{3 6}$ & $\mathbf{3 8}$ & 141 & 82 & 71 & $\mathbf{5 6}$ & $\mathbf{3 4}$ \\
\hline Mgr5-B 11 & 90 & 87 & 211 & 133 & 139 & 114 & 76 \\
\hline Mgr5-C 11 & $\mathbf{1 3}$ & $\mathbf{9}$ & 76 & $\mathbf{5 0}$ & $\mathbf{2 2}$ & $\mathbf{2 3}$ & $\mathbf{8}$ \\
\hline Mgr5-D 11 & $\mathbf{3 1}$ & $\mathbf{3 7}$ & 129 & 88 & $\mathbf{5 1}$ & $\mathbf{4 7}$ & $\mathbf{3 3}$ \\
\hline
\end{tabular}


Table 15: Comparison Bachelor and Master Aggregated Studies - Obligatory and Optionally Knowledge - Median

\begin{tabular}{|l|c|c|c|}
\hline Knowledge domain & Mgr 5 - 2005 & Mgr 5 - 2011 & Change \\
\hline MS01 Process modeling & 3 & 2 & $\downarrow$ \\
\hline MS02 Functionality and customization & 2 & 2 & $\rightarrow$ \\
\hline MS03 Management IS/ICT & 2 & 2 & $\rightarrow$ \\
\hline MS04 Analysis and design & 3 & 2 & $\downarrow$ \\
\hline MS05 Software engineering & 3 & 3 & $\rightarrow$ \\
\hline MS06 Data and information engineering & 3 & 3 & $\rightarrow$ \\
\hline MS07 IS/ICT knowledge & 3 & 3 & $\rightarrow$ \\
\hline MS08 Operational excellence & 2 & 3 & $\uparrow$ \\
\hline MS09 Team leadership skills & 2 & 3 & $\uparrow$ \\
\hline MS10 ICT market knowledge & 0 & 2 & $\uparrow$ \\
\hline MS11 Organizational management methods & 2 & 2 & $\rightarrow$ \\
\hline MS11 Organizational management methods & 1 & 2 & $\uparrow$ \\
\hline MS12 Enterprise finance and economics & 1 & 2 & $\uparrow$ \\
\hline MS13 Sales and marketing & 3 & 3 & $\rightarrow$ \\
\hline MS14 Mathematics & 2 & 2 & $\rightarrow$ \\
\hline MS15 Law & 0 & 0 & $\rightarrow$ \\
\hline
\end{tabular}

- When we compare our results for example with results presented in study (Varga et al., 2004) we see that the level of required knowledge is different in Czech Republic and in Croatia. For example, knowledge domain relevant to MS04 Analysis and design is more important in Croatia. The Czech results present that this domain has lower importance than other ICT knowledge domain.

- Other special Czech aspect is represented by business requirements on domain MS14 Mathematics. Knowledge of mathematics is held as ability and skill to apply logical thinking on problem identification and on problem solving. That is why mathematics skills are required in so high level in Czech conditions. Other surveys (for example at Curtin University of Technology - Cajander et al., 2010) present requirements on thinking skills and ability to apply discipline knowledge.

The lack of well-educated ICT professionals in economies is the main problem of ICT improvement into global society and into corporations as well. Low number of ICT experts in Czech economy cause lower innovation activities in this region in the comparison to USA, Japan and Canada. How to remove this disadvantage of Czech? Increase investments into schooling start to prepare new oriented ICT related study programs focused on required ICT business roles in order to remove the gap between supply and demand on the ICT specialist's labor market.

Secondary contributions of this project to ICT education development:
- Building up the network between businesses oriented experts, universities and middle schools in order to coordinate the education of ICT in the country.

- Setting up of the methodology for evaluation of competitiveness of ICT related study programs across the country and possibility their evaluation to business requirements.

- Evaluation of this methodology by practical surveys.

- Identification of gaps in ICT education system - missing courses and study programs for education for some business roles (for example IS Architect).

- Open issues:

口 investigation of macroeconomics characteristics of the ICT sector impact on the economy (some fact are presented for example in (Doucek et al., 2011a),

口 to analyze all in project described parameters in time scale (data series analysis).

\section{Acknowledgements}

Paper was elaborated with support of Grant Agency of the Czech Republic - projects P403/10/0092 Advanced Principles and Models of Managing Business Informatics“, "P403/11/1899 Sustainability Support of SME Based on ICT Innovation" and the IGA 409061 project of University of Economics, Prague.

\section{References}

Al-Jabri, I., M. \& Fraihat, H., M. (2005). Assessing Skills and Knowledge of IT Professionals in Saudi Arabia, Communications 
of the IIMA, 5(3), 63-76, Retrieved June 24, 2012, from http:// www.iima.org/CIIMA/CIIMA\%205.3\%2063\%20Al-Jabri-7.pdf

Bilmes, J. A. (1998). A Gentle Tutorial of the EM Algorithm and its application to Parameter Estimation for Gaussian Mixture and Hidden Markov Models, International Computer Science Institute, Retrieved 20.7. 2012 from http://crow.ee.washington. edu/people/bulyko/papers/em.pdf

Cajander, A., Daniels, M., McDermott, R. \& von Konsky, B., R. (2011). Assessing Professional Skills in Engineering Education. 13th Australasian Computer Education Conference (ACE 2011), Perth, Australia. Conferences in Research and Practice in Information Technology (CRPIT), Vol. 114. Eds. J. Hamer and M. de Raadt. Retrieved June 24, 2012, from www.it.uu.se/kata$\log / \mathrm{matsd} /$ CRPITV114Daniels.pdf

Clear, T. (2000). Thinking Issues, Practitioner Education - Degrees of Difference? SIGCSE Bulletin, 32(2, June 2000), 11 pages

Department of Labour (2005). Information Technology Professional: Occupational Skill Shortage Assessment. Department of Labour Te Tari Mahi. Retrieved June 23, 2012, from. http://www.dol. govt.nz/pdfs/professional-report-it.pdf

Doucek, P., Kunstova, R. \& Maryska, M. (2011a). Do We Have Enough ICT Specialists in the Period of eDependency? In: 24th Bled eConference "eFuture: Creating Solutions for the Individual, Organisations and Society”, June 12 - 15, 2011 [CD-ROM]. Maribor. University of Maribor, 2011, pp. 197-213.

Doucek, P., Pavlicek, A. \& Nedomova, L. (2011b). Information Management in Web 2.0 Technology Context. In: Strategic Management and its Support by Information Systems. September 5-7, 2011,Ostrava. VŠB TU Ostrava, 2011, pp. 34-45.

Doucek, P., Novotný, O., Pecakova, I. \& Vorisek, J, (2007). Lidské zdroje v ICT - Analýza nabídky a poptávky po IT odbornících $v$ České republice [Human Resources in ICT - Analysis of the Demand and Supply in Czech Republic] R. 1. ed. Praha: Professional Publishing.

European Commission (2010). Europe's digital competitiveness report. 2010 ISBN 978-92-64-08873-3 Retrieved June 5, 2012, from http://dx.doi.org/10.1787/it_outlook-2010-en

Fernandez, J. (2006). Evaluating, computing, education programs against real world needs. Journal of Circuits, Systems and Computers, 21(4), $259-265$.

Frinking, E., Ligtvoet, A., Lundin, P. \& Oortwijn, W. (2005). The Supply And Demand of E-Skills in Europe, September 2005, Prepared for the European Commission and the European e-Skills Forum, Retrieved April 20, 2012, from http://ec.europa. eu/enterprise/sectors/ict/files/eskills-2005-10-11.rand_en.pdf

Gala, L. \& Jandos, J. (2010). Enterprise Architecture Based Innovations: Competencies Perspective. In: 18 th IDIMT-2010 Information Technology - Human Values, Innovation and Economy. September 8-10, Jindřichův Hradec, Trauner Verlag, 2010, pp. 33-40.

Henno, J., Jaakkola, H. \& Mäkelä, J. (2012) Quo vadis, IT EDUCATION ? In: MIPRO 2012, May 21-25, 2012, Opatija, Croatia, pp. 1232- 1238.

Information (2012). ICT Professionals Shaping Our Future.ACS Employment Survey Report. ACS, 2012. Retrieved June 20, 2012, from http://www.acs.org.au/index.cfm?action=show\&co nID=skillassessment

ITCP. (2012). ITCP in Detail. Information Technology Certified Professional. Retrieved June 20, 2012, from http://www.itcp. org.nz/detail/areas

Jackson D. \& Chapman, E. (2012). Non-technical skill gaps in Australian business graduates. Education and Training, 54(2), $95-113$.

Jing, Q. \& Hoon, Ch. (2010). IT Certifications, Outsourcing and Information Systems Personnel Turnover, Information
Technology and People, 23(4), 330 - 351, http://dx.doi. org/10.1108/09593841011087798

Joseph, D., Ng, K.-Y., Koh, C. \& Ang, S. (2007). Turnover of information technology professionals: a narrative review, metaanalytic structural equation modeling, and model development, MIS Quarterly, 31: 547-577.

Kunstova, R. (2011). Changes in Position of the IT Department in Organizations In: $19^{\text {th }}$ Interdisciplinarity Information Management Talks. September 7-9, Jindrichuv Hradec. Trauner Verlag, pp. 71-78.

Lavalleé, P. (2007). Indirect Sampling. Springer Science and Business Media, 2007. ISBN 978-0-387-70778-5.

Marks, A. \& Huzzard, T. (2012). Employability and the ICT worker: a study of employees in Scottish small businesses. New Technology, Work and Employment, 25(2), 167 - 181.

Maryska, M. et al. (2012). Lidské zdroje v ICT - nabídka a poptávka $v$ České republice. [Human Resources in ICT - Supply and Demand in the Czech Republic], 1. vyd. Praha: Professional Publishing. ISBN 978-80-7431-082-9.

MacLennan, J., Tang, Z. \& Crivat, B. (2009). Data Mining with SQL Server ${ }^{\circledR}$ 2008. Wiley Publishing, Inc., Indianapolis, Indiana, 2009. ISBN: 978-0-470-27774-4

OECD (2010). Information Technology Outlook 2010. Paris: OECD Publishing ISBN 978-92-64-08873-3, http://dx.doi.org/10.1787/ it_outloook-2010-en.

Round, A. \& Lovegrove, G. (2004). First Destinations of UK Computing Graduates, A report based on data from 25 HEIs, Retrieved April 20, 2012, from http://www.cphc.ac.uk/docs/ ictgradreport.pdf

Saee, J. (2004). Internationalisation strategy for education in the 21ST century. Journal of Business Economics and Management 2004 (on-line), 5(2), 77-84, http://www.tandfonline.com/doi/ abs/10.1080/16111699.2004.9636071

Strawman, J. (2004). Computing Curricula 2004 Overview Report Including A Guide to Undergraduate Degree Programmes in Computing, Strawman Draft, ACM/AIS/IEEE, 1 June 2004, Retrieved April 15, 2012, from http://www.acm.org/education/ curricula.html

Thompson, S., K. (2012). Sampling (Wiley Series in Probability and Statistics), John Willey and Sons, Inc., 3rd Edition, 2012, ISBN 978-0-470-40231-3

Valenduc, G. \& Vendramin, P. (2005). Work organisation and skills in ICT professions: the gender dimension. Conference ICT, the Knowledge Society and Changes in Work. Den Haag, 9-10 June 2005, Workshop 1: ICT and skill change: opening the black box? Retrieved April 10, 2012, from http://www.dynamiseringvaninnovatie.nl

Varga, M., Stiffler, C. \& Stiffler, L. V. (2004). Evaluating IT Knowledge Requirements for Business Professionals. 26 th Int. Conf. Information Technology Interfaces ITI 2004, June 7-10, 2004, Cavtat, Croatia. Retrieved May 5, 2012, from http://bib.irb.hr/datoteka/149808.Evaluating_IT_Knowledge_ Requirements_for_Business_Professionals_ITI2004.pdf

Wickramasinghe, V. \& Perera, L. (2010). Graduates', university lecturers' and employers' perceptions towards employability skills, Education and Training, (3). 226 - 244, http://dx.doi. org/10.1108/00400911011037355

Petr Doucek heads the Department of System Analysis at University of Economics, Prague since 2007. His main topics in research and development work focus on information management, IS/ICT security management, project management and impacts of information society on economics and human. 
Lea Nedomová graduated the Natural Science Faculty at the Charles University, Prague in Pedagogy of Chemistry and Biology in 1992. She has been working as assistant professor of the Department of System Analysis at the Faculty of Informatics and Statistics at the University of Economics, Prague since 1996. Her main research and development topics include system approach to global society and sustainable development and its relation integrated management system - quality management, environmental management and sustainability.

Miloš Maryška has graduated at the Faculty of Informatics and Statistics at the University of Economic, Prague, in Information Technologies in 2006. In year 2010 has graduated in Applied Information Technologies and gained degree Ph.D. Since 2010 he has been working as a senior lecturer at the Department of Information Technologies at the Faculty of Informatics and Statistics at the University of Economics, Prague. Within his pedagogic and research work he focuses on management of economics of business informatics, Business Intelligence and ERP systems. He is co-author of 5 books, and author and co-author of several conference papers and in journal articles. In the company Lodestone Management Consultants works as a senior consultant and a team leader. 